\title{
Linking Human Rights and Development: Is there Value Gained or Lost?
}

\author{
Divane Nzima \\ University of Fort Hare \\ E-mail:dnzima@gmail.com \\ Vusumzi Duma \\ University of Fort Hare \\ E-mail:vduma@ufh.ac.za
}

\section{Doi:10.5901/mjss.2014.v5n1p475}

\begin{abstract}
This paper seeks to examine the possible benefits and losses that could accrue from linking human rights and development. The paper was prepared using a desktop research wherein various previous articles were examined to ascertain the extent to which the link between the human rights and development discourses is espoused. There have been growing debates regarding linking Human rights and Development. Leading multilateral development institutions such as the United Nations Development Programme (UNDP) and World Bank have also embraced the Human Rights- Development nexus. Considering the fact that both these discourses have existed in parallel for a very long time an attempt to merge them is likely to be met with some measure of resistance or acceptance. Therefore, this paper seeks to evaluate the extent to which the link between Human Rights and Development adds value or loss to the development agenda.
\end{abstract}

Keywords: Human Rights; Development; Rights Based Approaches; Accountability; Soveregnty.

\section{Introduction}

Recently there have been growing debates regarding linking Human rights and Development. Leading multilateral development institutions such as the United Nations Development Programme (UNDP) and World Bank have also embraced the Human Rights- Development nexus. This can be substantiated by a statement in the Human Development Report (2000:2) that says, "...human development is essential for realizing human rights, and human rights are essential for full human development." Furthermore, Wolfensohn, (2005:21) who is a former President of the World Bank, when addressing delegates at a Conference on Human rights and Development spoke about the nature of work they do at the World Bank and said, "...I have 10000 colleagues...they don't actually think they are any less strong than the rights activists....when you look at what they are dealing with, speaking candidly, it is everything that is in the rights agenda and the declaration and covenants." Though it seems the World Bank is reluctant to directly address the Human rights and Development relations, it is quite certain that this link is eminent as Wolfensohn, $(2005: 22)$ clearly notes when he says that, "...maybe we (World Bank) now need to mention the ' $R$ ' word which is 'rights'." This association of these two discourses that have for a long time been operating parallel to each other needs to be closely examined.

In this paper I will critically examine the possible benefits and challenges that can accrue from this link. According to the Human Development Report, (2000:2) "...The tradition of human rights brings legal tools and institutions-laws, the judiciary and the process of litigation-as means to secure freedoms and human development." It is mainly this normative nature of Human Rights Based Approaches (RBAs) to Development that sets them apart from other development approaches however despite this, there are other problem that come with this nexus such as the claims that RBAs unhelpfully re-politicize the development process, this tramples on sovereignty and emphasis on law exclude the poorest. (Robinson, 2005; Gready, 2008). This paper therefore is aimed at evaluating the extent to which the link between Human Rights and Development adds value or loss to the development agenda.

\section{The Meaning of Development and Human rights.}

In order to clearly understand the link between these two concepts it is important to understand their meaning. As quoted 
in Marx, (2005:23) the UNDP conceptualizes human development as "...creating an environment in which people can develop their full potential and lead productive, creative lives in accord with their needs and interest hence expanding the choices people have in order to lead lives they value." In addition, Marx, (2005:23) goes further to give us his conception of Human Rights when he says, "human rights are also about creating an environment in which people can develop their full potential and lead productive, creative lives by assuring the dignity and worth of a human person and promoting social progress and better standards of life in larger freedom..." The above shows that development and human rights can have an intersection. The aim of both these concepts is for the good of the masses, because by creating an enabling environment the end result is that people will be able to realize their full potential hence one can argue that these concepts are mutually reinforcing.

Once merged these concepts result in what are commonly known as the Rights Based Approaches (RBAs). According to Robinsons (2005:38) a "Rights Based Approach is a conceptual framework for the process of development that is normatively based on international human rights standards and operationally directed to promoting and protecting human rights...integrates the norms, standards and principles of the international human rights system into the plans, policies and processes of development." Drawing from the above, one may assume that the link between development and human rights results in a strengthened development framework built on firm ground. Albeit, this opinion will have to be further put to scrutiny in order to arrive at more concrete conclusions about the rationale of linking human rights and development. This scrutiny is even more relevant given the fact that, there is an introduction of law within the development arena, something that is not easily accessible in poor communities due to legal costs and poor institutions.

\section{Value Added to the Development Agenda}

\subsection{Empowerment through International Human Rights standards}

The principle of using international Human rights law as the basis for claiming rights can be seen as value that a rights framework adds to the development agenda. This point of departure makes it possible for those who are affected by poverty to lay claim to the government and non-state actors as right-bearers as opposed to just passive beneficiaries. As Filmer-Wilson (2005:217) rightfully notes, this framework "...identifies rights holders (and their entitlements) and duty bearers, and works towards strengthening the capacity of rights holders to claim and exercise their rights effectively and of duty bearers to fulfill their obligations towards such rights." Given the aforementioned sentiments one can therefore argue that linking human rights and development elevates the level of empowerment. It gives affected human beings a solid ground to stand on once their rights are violated. When people are conscious of their legal entitlements, be it to water, food or sanitation, they lay a claim backed by national and/or international law and the duty-bearers will understand that they are obligated to provide such a right and that the provision of such a right is not an optional act of charity. To further substantiate this opinion Filmer-Wilson (2005:217) argues that the emphasis on human rights boosts the self-esteem of poor people as they cease to be identified as victims and what was previously seen as charity is turned into justice.

Despite the value that comes with the link between human rights and development, there are concerns that such an invocation of distant international human rights standards may come with its own challenges. Cornwall and NyamuMusembi (2004:1418) argue that "...most poor people have little access to the institutions that might enforce their rights and that the interface between different legal systems governing their access to entitlements makes the process of recognizing and claiming rights complex." Given the above argument it is therefore essential for RBAs advocates to be open to other many strategies that may be utilized outside the realm of formal legal institutions in facilitating claims. In addition it could be argued that an empowerment such as one based on expectations for a duty bearer to fulfill an obligation is likely to create a culture of dependency. It cannot be disputed that invoking human rights standards can result in empowerment, however the argument here is that at times RBAs advocates must consider empowering people through the creation of self-reliance, hence they must be flexible to bringing other strategies on board as opposed to a rigid reliance on law or over emphasis thereof.

\subsection{Enhanced Accountability}

One of the major concerns within the development arena is the question of accountability. Development actors whether state or non-state should be accountable for their actions. It is argued that linking development and human rights translates to enhanced accountability (Robinsons, 2005:38). In addition Gready (2008:741) is of the opinion that 
"accountability is also often terrain where human rights are seen by the development fraternity as bringing value-added." What this therefore implies, is that all development actors including individuals in poor communities have the duty to respect and promote the realization of rights for all. In addition governments that have signed and ratified human rights treaties have the responsibility to fulfill obligations stated within those treaties. This therefore means that the issue of accountability assumes a legal backing. To further substantiate the above argument Ferguson (2011:4) argues that "...if a state violates a UN treaty or declaration that it is signatory to, the UN and its member states are responsible for enforcing legal accountability." Linking development and human rights adds value in such a way that the development agendas ceases to be national issues since states are no longer just accountable to their citizens but their failure to deliver invokes enforcement of legal accountability from other UN member states.

Though in International law the government is the primary duty bearer of rights, there are concerns as to the accountability of civil society and the donor community. One might argue that there is no direct accountability to those who benefit from programmes facilitated by Non-Governmental Organizations (NGOs), yet the same NGOs are always lobbying for state accountability. In support of this view Cornwall and Nyamu-Musembi (2004:1132) argue that "Direct accountability to the communities who are the ultimate recipients is non-existent. This is as much, if not especially, the case for NGOs, most of whom lack any defined accountability and are even less amenable to being held to account than multilateral or bilateral development actors." This lack of direct accountability for NGOs posses problems, because it raises questions such as - If they are not accountable to their direct beneficiaries, to who are they accountable then? In addition it becomes very difficult to trust their activities given the fact that most of them are foreign sponsored hence are at risk to be labeled as the advocates of the same old neo-liberal agenda dressed in the coat of a rights based approach. As a result Chapman et al (2005:26) argue that agencies and NGOs must consider becoming critically self-aware and address inherent power inequalities in their interaction with poor communities because accountability is central to the rights based approach. In addition she also gives an example of Action Aid in Kenya and their efforts in attempting to be accountable to the people they serve. An excerpt from her example reads, "All our reviews and reflections are conducted by poor people and community organizations in the field and not on paper. Poor people question their own community organizations and Action Aid on what they have done, what has worked, what they didn't like, what should change."(Chapman et al, 2005:26). A human rights approach will be much more valuable to development if all actors including NGOs thrive for openness and hence commit to high standards of accountability especially to the poor people who are their primary beneficiaries. Pushing for government accountability without doing the same will only amount to mediocrity on the part of civil society, however on the part of government it cannot be disputed that RBAs bring about enhanced accountability because this is grounded in international law.

\subsection{Active participation}

The people who are affected by poverty are the ones who know best about their situation. In addressing the question of development it would be unwise not to heed the voices of the poor in designing and implementing development policies. Poor people must actively participate in the development process in their communities. It can therefore be argued that a development framework that seeks to impose policies on the poor based on perceived needs is likely to be doomed from the start. In qualifying the value of linking development and rights, Filmer-Wilson (2005:219) argues that "the RBA requires that poor and marginalized groups participate in identifying their own development objectives. They must then be actively involved in designing and implementing projects to meet their needs." The inclusive approach that the RBAs seek to follow presents opportunities for success. As Filmer-Wilson (2005:219) would concur, this approach creates an environment that facilitates ownership of the development process and allows beneficiaries to actively advocate for programmes that they can sustain with the capabilities they have. In addition Archer (2006:99) argues that this paradigm of rights based approaches to development "emphasizes the potential in development planning of rights such as individual freedoms and local community participation." When people are given the freedom to choose the kind of development they want for their communities, development planning is likely to address their core needs and as such success in the development projects is likely to follow. It can thus be argued that people and their communities can only be truly free once they are able to participate and exercise their freedoms especially the freedom of choice. The RBAs seem to promise this true emancipation for poor communities as Archer (2006:99) would concur.

\section{Human Rights - Development Interactions: Value Lost}

\subsection{Politicizing development unnecessarily.}


The emergence of International Human Rights law in the development scene, bringing in opportunities of enhanced accountability, empowerment and participation, principles that are widely celebrated also poses challenges for the discourse of development. According to Robinson (2005:32) development specialists accuse human rights of unhelpfully politicizing the process of development. She further reiterates that these concerns are inspired by too much focus on the state and the adversarial and judgemental nature of monitoring state performance which in the end raises concerns about impediment on sovereignty. One can argue that concerns are even made worse by the inequalities that exist between states wherein some states are donors while others are recipients of aid. While appealing to international human rights standards may be seen as trampling on national sovereignty Jha (2012:20) adds that "national development programmes may be funded by international agencies/supporting country only if such interventions meet the objectives of donor countries/agencies and international policy prescriptions." Due to these inequalities, poor countries end up sacrificing their right to self-determination. Therefore the picture that is painted here is that by calling upon international human rights standards and putting too much focus on the state, the development process is indeed overly politicized. Poor countries find themselves between a rock and hard place. They are forced to take conditional aid and lose ownership of the development process or reject aid and face the wrath of international law and harsh criticism over failure to meet their obligations.

Advocates of human rights in development, however still feel that, re-politicizing development somewhat adds value to development (Gready, 2008:742). In addition Robinson (2005: 32) acknowledges that human rights frameworks do have an adversarial and critical approach on the state however she point out that some groups are also shifting their focus to other actors such as business. Furthermore, she down plays the issue of sovereignty and the power play that is involved between rich and poor states in relation to the subject of human rights. One may therefore suggest that it could be wise for advocates of human rights to keep an open mind in dealing with development. As much as they stress the attainment of minimum standards as agreed by the international community as Robinson (2005:33) would argue, they should keep in mind that an adversarial approach creates problems as poor states may feel threatened given the background that most of the NGOs are sponsored by external government whose interests may be meeting their foreign policy objectives. To substantiate this caution and justify the skepticism over the political nature of RBAs, Jha (2012:20) argues that, "Most donor countries deploy development aid as a tool in their foreign policy. They use aid as a leverage to attain their foreign policy objectives."Once aid has been received, poor countries are expected to account for it based on conditions accompanying the aid, which as has been argued may be aimed at meeting donor's foreign policy objectives while using the rights language. This therefore may be the basis for the argument on sovereignty which Robinson (2005:32) has down played in her argument.

\subsection{Lack of flexibility.}

Despite being unnecessarily political, human rights are also accused of being inflexible and over emphasizing the present, this is another value lost in linking human rights and development. To support this opinion, Archer (2006:83) argues that human rights advocates "...think only in the present tense, and allow only unidirectional progress. This approach, it is argued, is deeply at odds with the experience of development." Development is an ongoing process, sometimes people have to forgo certain things at present in order to achieve more in the future. However, human rights advocates are blind to this reality; hence Archer (2006:83) points out that "human rights advocates are not able to balance benefits for the many against loss for a minority, or great benefits in the future against manageable loss now." This impatience and thirst for instant reform is something that one can argue rights advocates need to drop if linking development and human rights is to be a realistic discourse. Robinson (2005:36) acknowledges that human rights experts have not put enough thought about the above concerns. However she points out that things are as they are because Human rights proponents tend to focus on those who are marginalized and do not benefit from development regardless the fact that the majority might have benefited. Hence to her this can still be adding value to development planning since attention can be forced on those who do not benefit from development.

\subsection{Challenges in practical application.}

The human rights-development nexus is not only devalued by the over politicization of development and inflexibility. However, it is also accused of being difficult to apply practically. This argument is postulated in a statement by FilmerWilson (2005:220) when she states that, "...translating a comprehensive set of legal statements into development policy at country level is a complex process. Equally, systematically applying human rights principles into development 
programming is proving a challenge..." From the argument above, one can derive that translating international law into development policy and programming is a challenge. Maybe the major challenge, it could be argued is the fact that since all rights are equally important by law, how can development policy cater for all, given limited capacity to fulfill them all. As Robinson (2005:34) also notes, rights proponents "...find it difficult to bargain- to set aside protection of one right in favour of protecting another." Development is determined by the financial capacity a country has, hence at times there is a need to prioritize certain rights over others in order to achieve certain development goals in accordance with the capacity. The challenge therefore is that human rights present an ideal development programming which is a challenge to apply practically. Though Robinson (2005:35) would defend this accusation by arguing that human rights consider budgetary constraints and suggests that if they were impractical, state parties would not have agreed to them, it would perhaps be important to note that when human rights were adopted they were operating parallel from the development discourse, now that these two discourses are being merged, certain adjustments are necessary such as putting in place criteria for choosing between two goods.

\section{Conclusion}

In this paper some of the benefits and challenges of linking human rights and development were critically examined. Focus was directed to perceived benefits such as empowerment through international human rights standards, enhanced accountability and active participation. It was argued that these elements do add value to the link between human rights and development. However it was also argued that they also have their shortcomings which were pointed out in this paper. In addition perceived challenges were argued for, these include the notion that human rights politicize development unnecessarily because they lack flexibility and are impractical. In conclusion therefore one can argue that linking development and human rights adds value to an extent that development is more people centered and there is a clear normative framework to derive development objectives. However there are few adjustments needed from the human rights advocates in order to find common ground with development experts as has been argued in this paper.

\section{References}

Archer, R. (2006). "The Strengths of Different Traditions: What Can be Gained and What Might be Lost by Combining Rights and Development?" International Journal on Human Rights, Vol. 3(4) pp (80-89).

Chapman, J, Miller, V, Soares, A. C and Samuel, J. (2005). Rights-Based Development: The Challenge of Change and Power. Global Poverty Research Group (GPRG) Conference Paper. Accessed at http://www.gprg.org/ on 25/02/2013 at 2.00pm

Cornwall, A and Nyamu-Musembi, C. (2004). "Putting the 'rights-based approachess to development' into perspective." Third World Quarterly, Vol. 25(8), pp (1415-1437).

Ferguson, H. (2011). The Right to Development and the Rights - Based Approach to Development: A Review of Basic Concepts and Debates. New Delhi: Centre for Development and Human Rights. Occasional Paper No. 1.

Filmer-Wilson, E. (2005). "The Human Rights Based Approach to Development: The Right to Water." Netherlands Quarterly of Human Rights, Vol. 23(2) pp (213-241).

Gready, P. (2008). "Rights-Based Approaches to Development: What is the Value Added?" Development in Practice, Vol. 18(6) pp (735747).

Jha, S. (2012). "A Critique of Right to Development." Journal of politics and Governance, Vol. 1(4) pp (17-22).

Marks, S. P. (2005). The Human Rights Framework for Development: Seven Aproaches, in Sengupta A, Negi A and Basu M, (eds). Reflections on the Right to Development, pp (23-60). New Delhi: Sage Publications.

Robinson, M. (2005). What Rights Can Add to Good Development Practice, in Alston P and Robinson M (eds). Human Rights and Development: Towards Mutual Reinforcement, pp (25-41). New York: Oxford University Press.

United Nations Development Program. (2000). Human Development Report 2000 Summary. New York: UNDP/Oxford University Press.

Wolfensohn, J. D. (2005). Some Reflections on Human Rights and Development, in Alston P and Robinson M (eds). Human Rights and Development: Towards Mutual Reinforcement, pp (19-24). New York: Oxford University Press. 
